\title{
Glucocorticoid receptor activation following elevated oocyte cortisol content is associated with zygote activation, early embryo cell division, and IGF system gene responses in rainbow trout
}

\author{
Mao Li, John F Leatherland, Matt M Vijayan", W Allan King and Pavneesh Madan \\ Department of Biomedical Sciences, University of Guelph, Guelph, Ontario, Canada N1G 2W1 \\ ${ }^{1}$ Department of Biology, University of Waterloo, Waterloo, Ontario, Canada N2L 3G1 \\ (Correspondence should be addressed to P Madan; Email: pmadan@uoguelph.ca)
}

\begin{abstract}
Increased in ovo cortisol content of rainbow trout oocytes from $\sim 3.5$ to $\sim 5.0$ ng.oocyte ${ }^{-1}$ before fertilization enhances the growth of embryos and juveniles and changes the long-term expression pattern of IGF-related genes. This study used embryos reared from oocytes enriched with cortisol and the glucocorticoid receptor (GR) antagonist, RU486, to determine whether the growth-promoting actions of cortisol involve GR protein activation and modulation of $\mathrm{gr}$ expression. Whole-mount in situ immunohistofluorescence studies of zygotes showed that enhanced oocyte cortisol increased the immunofluorescent GR signal and activated the relocation of GR from a general distribution throughout the cytoplasm to an accumulation in the perinuclear cytoplasm. In ovo cortisol treatment increased the number of embryonic cells within 48 -h post-fertilization,
\end{abstract}

and RU486 partially suppressed this cortisol stimulation of cell duplication. In addition, there was complex interplay between the expression of $g r$ and igf system-related genes spatiotemporally in the different treatment groups, suggesting a role for GR in the regulation of the expression of development. Taken together, these findings indicate an essential role for GR in the regulation of epigenomic events in very early embryos that promoted the long-term growth effects of the embryos and juvenile fish. Moreover, the pretreatment of the oocyte with RU486 had a significant suppressive effect on the maternal mRNA transcript number of $g r$ and igf system-related genes in oocytes and very early stage embryos, suggesting an action of antagonist on the stability of the maternal transcriptome.

Journal of Endocrinology (2012) 215, 137-149

\section{Introduction}

Cortisol of maternal origin is present in the oocytes and embryos of several fish species (reviewed by Leatherland et al. (2010)), and maternal plasma cortisol levels during the period of oocyte vitellogenesis determine oocyte cortisol content (Eriksen et al. 2006, 2007, Veillette et al. 2007, Leatherland et al. 2010). In salmonid fish, increased oocyte cortisol content brings about changes in the embryonic epigenome, resulting in changes in the phenotype of the progeny ( $\mathrm{Li}$ et al. 2010, 2011, Eriksen et al. 2011). In addition to its potency as a regulator of intermediary metabolism in fish (Leatherland 2010, Vijayan et al. 2010), cortisol is involved in several aspects of normal gametogenesis and embryogenesis in fish. These include oocyte maturation and hydration (Milla et al. 2006, 2009, Leatherland et al. 2010, 2012), hatching (Barry et al. 1995, Sampath-Kumar et al. 1995), sex differentiation (Hayashi et al. 2010, Yamaguchi et al. 2010), embryo growth (Eriksen et al. 2006, 2007, Li et al. 2010), and modulation of the embryonic immune response ( $\mathrm{Li}$ et al. 2011). Thus, elevated cortisol levels in the oocytes, and therefore in early embryonic cells, have the potential to interfere profoundly with many aspects of normal embryogenesis (reviewed by Leatherland et al. $(2010,2012))$.

In mammals, maternal stressor-related increases in cortisol delivery to the embryo have been associated with increases in embryo mortality, smaller progeny, depressed immune function, reduced adrenal and gonadal mass, behavioral and morphological alteration, increased activation of the sympathetic nervous system, various neurological disorders, and impaired stress responses (reviewed by Godfrey et al. (2010), Matthews \& Phillips (2010) and Hochberg et al. (2011)). Far less is known about the actions of cortisol and the effects of maternal cortisol levels on the early development of fish embryos; this study attempts to enhance current knowledge pertaining to the effects of maternal cortisol on early developmental events, particularly actions on the epigenome that determine the juvenile or adult physiological phenotype.

In recent studies, we found that an increase in oocyte cortisol content in rainbow trout (Oncorhynchus mykiss) oocytes from $\sim 3.5$ ng.oocyte ${ }^{-1}$ (untreated) to $\sim 5 \cdot 0$ ng. oocyte ${ }^{-1}$ (cortisol treated) before fertilization resulted in an increase 
in the growth of embryos and adults reared from these oocytes (Li et al. 2010). This one-time exposure could not be explained on the basis of increased feeding efficiency or changes in $\mathrm{GH}$ secretion, but the growth responses were associated with changes in the patterns of the expression genes encoding insulin-like growth factors (IGFs), GHs, and their receptors. In particular, in the embryos reared from cortisolenriched oocytes, igf1 expression was significantly enhanced from the zygote to 21-days post-fertilization (dpf) embryos and igf 2 was enhanced in the 21-dpf embryos (Li et al. 2010). The mechanistic link between the one-time exposure of oocytes to elevated cortisol levels to the long-lasting growth promoting action has yet to be established.

This study was undertaken to determine whether these very early embryonic responses to cortisol were associated with the interaction of the hormone with glucocorticoid receptors (GRs; Veleiro et al. 2010). GRs, together with gr mRNA transcripts, are ubiquitous in the cytosol of postembryonic cells (reviewed by Leatherland et al. (2010), Schreck (2010) and Vijayan et al. (2010)). Before ligand activation, the GRs are associated with chaperone molecule complexes (reviewed by Leatherland et al. (2010)). Ligandactivated GR dissociates from the chaperone complex and translocates toward the nucleus in association with skeletal microfibrils in the cytosol (Heitzer et al. 2007, Fitzsimons et al. 2008) the activated GR then enters the nucleus via the nuclear pores. Within the nucleus, the GR interacts with DNA in the promoter region of many genes, acting as a transcription factor. In this study, we examine whether changes in in ovo cortisol content in the presence or absence of the steroid receptor antagonist, RU486 (mifepristone), affected GR activation and translocation in the zygote. The study also examined the effects of in ovo cortisol (in the presence or absence of RU486) on the rate of early cell division of the embryo and the expression of $g r$ and igf genes during the period of increased embryo genome activation (Li et al. 2007, 2010).

\section{Materials and Methods}

\section{Experimental design, collection of gametes, and fertilization process}

The University of Guelph Animal Care Committee approved the experimental protocols used in this study. All experiments were conducted at the Alma Aquaculture Research Station (Alma, ON, Canada).

The collection and processing of oocytes for in ovo treatments were as described for previous studies (Raine et al. 2004, Aluru et al. 2010, Li et al. 2010, 2011). Milt and naturally ovulated oocytes were collected from five male and five female $3+$ year-old rainbow trout (O. mykiss), respectively, during the peak ovulatory period (mid-October). For 6 weeks before this, the female fish were examined weekly to determine whether ovulation had occurred, and if so, to harvest the oocytes from the peritoneal cavity of each fish by lateral palpation of the abdomen. Thus, for the mid-October collection, the maximum duration of the retention of the oocytes in the peritoneal cavity was 7 days, which for salmonid fish does not result in biochemical changes that lead to over-ripening and loss of fertility of the oocytes (Lahnsteiner 2000, Bahrekazemi et al. 2009).

The oocytes and accompanying ovarian fluid of five fish collected on the same day were pooled and gently mixed together to ensure homogeneity, before randomly allocating equal volumes of oocytes to the treatment groups for a 3-h prefertilization treatment as described below. Following the incubation, an aliquot of the milt pool was added to each group and the oocytes and milt were gently mixed together. A small volume of water was then added and mixed with the oocytes/ovarian fluid to activate the sperm; the excess milt was then rinsed from the mix by introducing a slow stream of water into each container. The eggs were then left undisturbed to allow their zona pellucida to begin the water hardening process. Following water hardening, the fertilized oocytes of each treatment group were randomly assigned among custom-designed Plexiglas wells in Heath incubator trays for rearing of the embryos (three replicates per treatment group).

This protocol was adopted because it introduces some genetic variation in the stock of oocytes before their allocation to different treatments, and it has been found to produce repeatable responses both within and between sampling seasons in studies of factors that affect embryo gene expression (Li et al. 2010). For purposes of consistency, this paper describes the results obtained from a single reproductive season (Fall of 2008); however, independent measures of fertilization and hatching rates were observed in two reproductive seasons (Fall of 2008, 2009), and cell counts involving confocal imaging were observed in three reproductive seasons (Fall of 2008, 2009, Spring of 2009). In all cases, the findings from the three reproductive seasons exhibited a similar among-treatment pattern of responses (Li 2011).

\section{Cortisol and RU486 treatments of ovulated oocytes}

A pool of $\sim 10000$ oocytes were divided into four treatment groups of approximately equal size for prefertilization incubation. The oocytes were immersed either in ovarian fluid alone or in ovarian fluid containing cortisol (hydrocortisone; Sigma) with or without RU486 (mifepristone; Sigma) to form the four treatment groups: control (Con), cortisol treatment $(\mathrm{Ct})$, RU486 treatment (RU), and cortisol+RU486 treatment $(\mathrm{Ct}+\mathrm{RU}))$. The final concentrations of cortisol and RU486 were 100 and $1000 \mathrm{ng} / \mathrm{ml}$ ovarian fluid respectively. The cortisol- and RU486-enriched ovarian fluid was prepared by mixing $0 \cdot 1 \%$ by volume of an ethanol stock solution of the compounds to the ovarian fluid; an equal volume of ethanol alone was added to the ovarian fluid of the control group. Previous studies (Li et al. 2010) have shown that incubating rainbow trout oocytes in ovarian 
fluid containing $100 \mathrm{ng} / \mathrm{ml}$ cortisol increases the oocyte cortisol content from $\sim 3.5$ ng.oocyte ${ }^{-1}$ in the untreated group to $\sim 5 \cdot 0$ ng.oocyte ${ }^{-1}$. The oocyte concentrations of the steroid RU486 could not be measured, but it was assumed that the partitioning of RU486 between the ovarian fluid and the ooplasm was similar to that for cortisol. The concentration of RU486 in the ovarian fluid was in a range that has been shown to have antagonistic effects on GR function in several species of fish (Vijayan et al. 1994, Aluru et al. 2004, Scott et al. 2005, Veillette et al. 2007, Vizzini et al. 2007, Alderman et al. 2012).

The incubations were carried out in the dark for $3 \mathrm{~h}$ and the oocytes were then fertilized, water hardened, and aliquots were placed in Heath incubator trays for the rearing of the embryos, as described earlier. Throughout the embryo rearing period, the Heath incubators were supplied with constantly running aerated well water at $8.5^{\circ} \mathrm{C}$. The embryos were reared in the trays until just before the 'swim up' stage (51 dpf) when they were transferred to $0.7 \mathrm{~m}^{3}$ grow-up tanks for transition from late-stage embryos to exogenously feeding early-stage embryos.

The fertilization rate was calculated at the eyed-stage embryos (26 dpf) and expressed as a percentage of the total number of prefertilization oocytes. The hatching rate was calculated as the number of hatched live embryos ( $38 \mathrm{dpf}$ ) as a percentage of the total number of prefertilization eggs. The mortality rates were calculated by counting the surviving embryos at $51 \mathrm{dpf}$ (swim up stage) and $62 \mathrm{dpf}$ (just before first feeding); the values are expressed as the percentage of the total number of hatched live embryos.

Whole-mount in situ immunostaining of GR protein in zygotes

Zygotes collected at 2-h post-fertilization (hpf) were fixed in $4 \%$ paraformaldehyde in PBS ( $\mathrm{pH} \mathrm{7 \cdot 5)}$ for $4-6 \mathrm{~h}$, washed several times in PBS, and maintained in PBS at $4{ }^{\circ} \mathrm{C}$ for whole-mount in situ immunohistochemical staining, which was carried out within 14 days of fixation.

The zona pellucida of each 2-hpf zygotes was removed before the whole-mount in situ GR immunofluorescence staining, and the denuded zygotes were placed in 72-well microplates (Nalge Nunc, Rochester, NY, USA). The protocol used was that described previously by Madan et al. (2007). Briefly, the denuded zygotes were incubated at room temperature for $1 \mathrm{~h}$ in 5\% donkey serum in PBS containing $0 \cdot 01 \%$ Triton X-100 to eliminate nonspecific antibody binding and then washed twice in $1 \%$ donkey serum in PBS containing $0 \cdot 005 \%$ Triton X-100 for $30 \mathrm{~min}$ in each at $37^{\circ} \mathrm{C}$. The primary GR antibody used was anti-trout GR IgG serum raised in rabbits (Sathiyaa \& Vijayan 2003). This antibody has been proven to be an effective GR anti-serum in rainbow trout (Vijayan et al. 2003, Aluru et al. 2004, Gravel \& Vijayan 2006). The antibody was used at a 1:500 dilution in PBS. The denuded zygotes were incubated overnight at $4{ }^{\circ} \mathrm{C}$; negative controls were incubated in PBS alone. The samples were then washed three times for $30 \mathrm{~min}$ at $37^{\circ} \mathrm{C}$ in PBS, followed by incubation in a secondary antibody (donkey anti-rabbit IgG conjugated with Alexa Fluor 488 (FITC; Invitrogen)) for $1 \mathrm{~h}$ at $37^{\circ} \mathrm{C}$. The denuded zygotes were then washed twice in PBS in darkness at $37^{\circ} \mathrm{C}$ and treated with 4,6-diamidino-2-phenylindole (DAPI; 1:2000) for 20-30 min, followed by three 20- to 30-min washes in PBS. Finally, the denuded zygotes were mounted on slides in Vectashield mounting medium (Fluorguard) for fluorescence staining (Vector Laboratories, Inc., CA, USA); from this point, the zygotes were protected from light. Fluorescence images were taken using a Zeiss LSM 410 confocal microscope (Olympus Canada, Markham, ON, Canada; $10-40 \times$ objective magnification at $405 \mathrm{~nm}$ wavelength (for DAPI) and $488 \mathrm{~nm}$ wavelength (for FITC)). The images were then captured and stored as TIFF files; Z-stack images by Z-scan were saved as Multiview TIFF files and analyzed by the Zeiss LSM Software package.

\section{Cell counts in early embryos}

Paraformaldehyde-fixed embryos from 18 to $48 \mathrm{hpf}$ were placed in 72-well microplates, washed several times in PBS, and incubated in DAPI $(0.5 \mu \mathrm{g} / \mathrm{ml})$; the incubation was carried out at room temperature, in the dark, for 20-30 min depending on the size of the embryo. The embryos were then washed several times in PBS to remove background staining and mounted on slides. Images of the DAPI-stained embryos were taken under a u.v. microscope, and the number of embryonic cells or nucleoli was counted depending on the stage of the embryos. For embryos older than $36 \mathrm{hpf}$, it was not possible to identify individual cells because of the small cell size and large number of cells; however, the nucleoli were visible, and therefore, counts of nucleoli were used as a relative indicator of the number of cells. Image-Pro Software (Media Cybernetics, Inc., Silver Spring, MD, USA) was used to count the nucleoli from chosen areas of the embryo images (at least five counts per image, five to ten embryos for each stage in total); manual counts were made to verify the software count numbers.

Total RNA content, relative gene expression ratios, and the correlation between the expression of genes encoding for GR and IGF system components

Zygotes or whole embryos were taken immediately after fertilization (t0) and again at 1, 2, 7, and $13 \mathrm{dpf}$. All samples were fixed in RNAlater (Ambion, TX, USA) for the extraction of total RNA. Five to ten RNAlater-fixed oocytes or embryos were pooled for each sample (depending on size), and the total RNA extracted as described previously (Li et al. 2007). Qiagen RNeasy Mini kits (Qiagen Science) were used to isolate embryo total RNA, and the RNA extracts were treated with DNase I to remove any genomic DNA following the manufacturer's instructions. The extracted RNA was quantified by NanoDrop (Thermo Scientific, 
Table 1 Effects of in ovo cortisol and RU486 treatments on the fertilization rates of oocytes and the hatching and mortality rates of embryos between hatching and swim up (51 dpf) and hatching and first feeding (64 dpf)

\section{Treatment groups}

$\begin{array}{lrrrr}\text { Fertilization (\%) } & 89 \cdot 8 & 94 \cdot 0 & 92 \cdot 7 & 95 \cdot 0 \\ \text { Hatching (\%) } & 74 \cdot 1 & 77 \cdot 6 & 75 \cdot 3 & 73 \cdot 9 \\ \begin{array}{l}\text { Mortality: hatching to } \\ \quad \text { swim up (\%) }\end{array} & 4 \cdot 5 & 2 \cdot 1 & 2 \cdot 0 & 2 \cdot 7 \\ \begin{array}{l}\text { Mortality: hatching to } \\ \quad 7 \cdot 8\end{array} & 6 \cdot 7 & 10 \cdot 3 & 11 \cdot 3\end{array}$

Washington, DC, USA), and the total amount of RNA per embryo was determined.

A $1 \mu \mathrm{g}$ sample of the DNase I-treated total RNA was reverse transcribed into cDNA using a high-capacity cDNA reverse transcription kit (Applied Biosystems) following the manufacturer's instructions. A $20 \mu \mathrm{l}$ sample of the cDNA synthesis reaction was diluted $1: 5$ by volume with DNase-free water to prepare the working solution of the CDNAs in the real-time PCR gene quantification. Four replicates of cDNA from each treatment were produced in this study. Cytoplasmic actin gene (GenBank no: CB 494180) was used as the housekeeping gene; this gene had been found to be a suitable housekeeping gene by the Bestkeeper Software program for embryo developmental work (Pfaffl et al. 2004, Li 2011). A relative expression method for developmental embryos was used to quantify the expression of $g r 1, g r 2$, igf1, igf2, igf-rIa, and igf-rIb genes as described previously (Li \& Leatherland 2008), in which each gene was quantified against its standard and then normalized to the housekeeping gene. In order to examine the correlation between gene expression, additional replicates of total RNA and cDNA were made from each of the four treatment groups of the 7-dpf embryos.

\section{Statistical analysis}

Data pertaining to the treatment effects on early embryo cell numbers, total RNA content of early embryos, and relative gene expression were analyzed by one-way ANOVA to examine the differences during embryo development in each treatment and within each development stage among the treatments. Where tests for normality or equal variance failed, Kruskal-Wallis's one-way ANOVA on ranks was used, followed by Dunn's pair-wise multiple comparison method. Where $F$ values indicated statistical significance $(P<0 \cdot 05)$, the Holm-Sidak multiple comparison or Student-Newman paired comparison method was performed. Data pertaining to rates of fertilization, hatching, and mortality were analyzed by $\chi^{2}$ analysis. The relationship of the relative gene expression between grs and igfs in the 7-dpf stage of embryos was tested using Pearson's correlation analysis. For all statistical tests, a probability level of $P<0 \cdot 05$ was considered to be significant.

\section{Results}

Oocyte rates of oocyte fertilization, embryo hatching, and mortality

As shown in Table 1, there were no significant differences in the percent fertilization of oocytes, the rates of hatching of the embryos, the morbidity rates from hatching to $51 \mathrm{dpf}$, or the hatching rates to $64 \mathrm{dpf}$ among the four treatment groups.

\section{Zygote activation, early cell division, and GR distribution in early embryonic cells}

Following fertilization, the cytoplasm of the zygote migrated rapidly to the animal pole and formed a thin layer overlying the yolk. In fresh tissue, it appeared that partially digested droplets of yolk surrounded and underlay the zygote, whereas in the $4 \%$ paraformaldehyde-fixed tissues, the early cells overlaid a cone-like region of digested yolk (Fig. 1).

In the whole-mount in situ GR immunofluorescent preparations of 2-hpf zygotes of the Con and RU treatment groups, the immunofluorescence signal was dispersed throughout the cytosol, with no indication of perinuclear aggregation of immunofluorescence (Fig. 2e, f1, f2, k and l). Conversely, in the 2-hpf zygotes that were reared from oocytes of the two cortisol treatment groups $(\mathrm{Ct}$ and
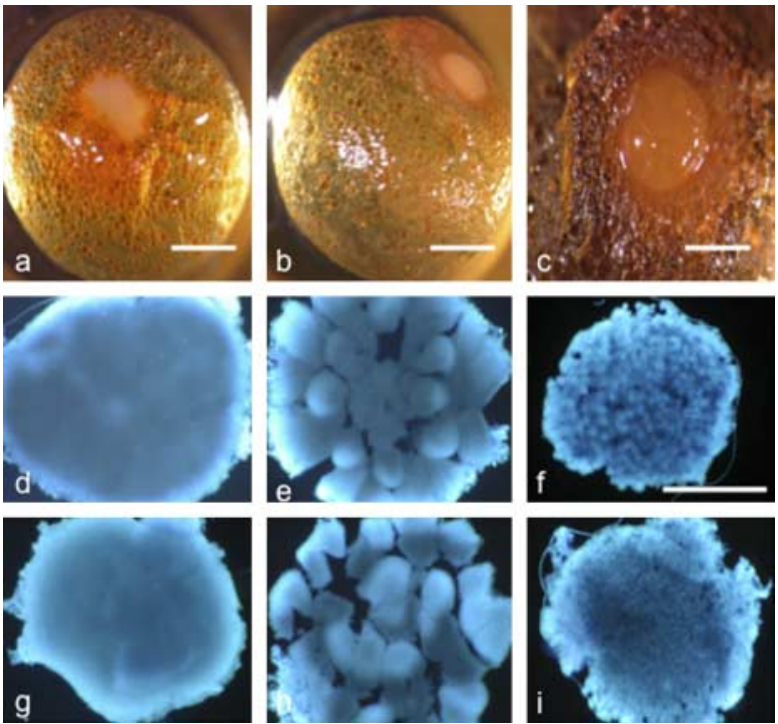

Figure 1 Whole-mount light microscopic images of rainbow trout early embryos: (a, b, and c) show eggs fixed in $4 \%$ paraformaldehyde at 2 hpf (zygote; a), 12 hpf (four-cell embryo; b), and $18 \mathrm{hpf}$ (eight-cell embryo; c). The bar represents $100 \mu \mathrm{m}$. (d and e) show embryos reared from oocytes that were incubated in ovarian fluid alone, before fertilization (control): (d, e, and f) show 18-, 24-, and 48-hpf embryos respectively. (g, h, and i) show embryos reared from oocytes that were incubated in cortisol-enriched ovarian fluid for $3 \mathrm{~h}$ before fertilization (cortisol treatment): $(\mathrm{g}, \mathrm{h}$, and i) show 18-, 24-, and 48-hpf embryos respectively. The bar in (f) represents $50 \mu \mathrm{m}$. Full colour version of this figure available via http://dx.doi. org/10.1530/JOE-12-0030. 


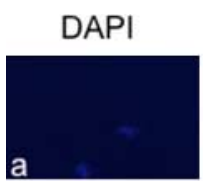

\section{FITC}
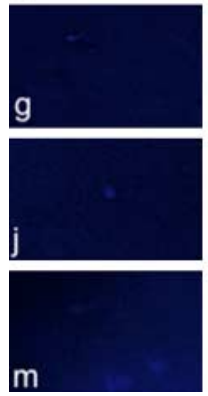
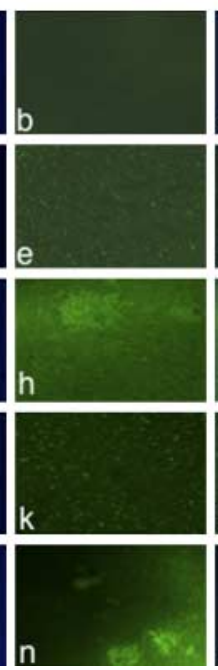

\section{Overlay}
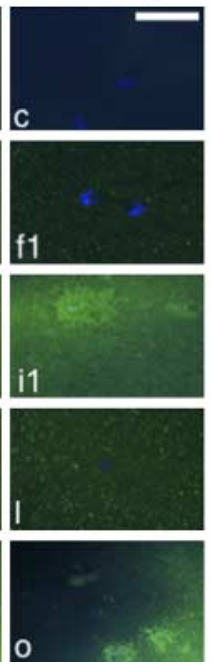
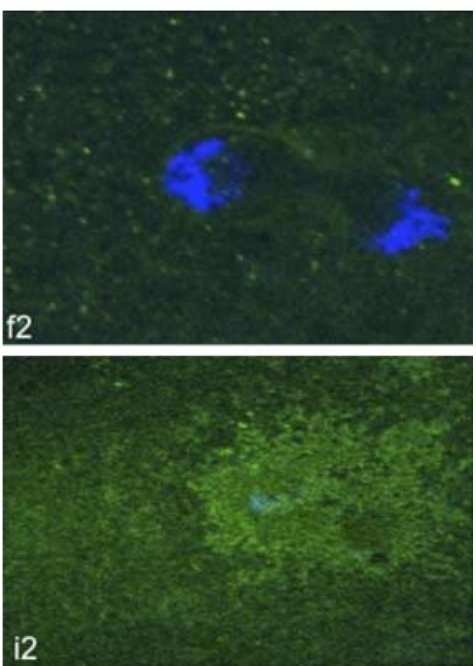

Figure 2 Whole-mount in situ GR immunohistofluorescence confocal microscopic images taken by confocal microscopy, showing the effects of incubation of oocytes in ovarian fluid alone (control; d, e, f1 and f2), or ovarian fluid enriched with cortisol alone (cortisol treatment; $\mathrm{g}, \mathrm{h}, \mathrm{i} 1$ and i2), RU486 alone (RU486 treatment; j, k, and I), or cortisol and RU486 together (cortisol + RU486 treatment; $\mathrm{m}$, $\mathrm{n}$ and o) on the distribution of GR distribution in the zygote. (a, b, and c) are negative controls (no primary GR antibody in the control group). For each row, the left-hand column is DAPI stained, the middle column is stained with the fluorescence dye Alexa Fluor 488-labeled (FITC) donkey anti-rabbit IgG conjugated with/without rabbit anti-trout GR antibody (primary antibody), and the right-hand column is the overlain images. ( $f 2$ and $\mathrm{i} 2$ ) are enlarged images of figures $\mathrm{f} 1$ (control) and i1 (cortisol treatment) respectively. Full colour version of this figure available via http://dx.doi.org/10. 1530/JOE-12-0030.

$\mathrm{Ct}+\mathrm{RU})$, in addition to a marked increase in the immunofluorescent signal relative to the non-cortisol treatment groups, there was a distinct aggregation of the GR in the cytosol surrounding the nucleus (Fig. 2h, i1, i2, n and o).

The effects of cortisol and/or RU486 treatment of oocytes on early embryo cell proliferation

There were four cells in the 12-hpf and eight cells in the 18-hpf embryos (Fig. 1b and c), indicative of a 6-h cell cycle for rainbow trout embryonic cells maintained at an ambient temperature of $8 \cdot 5^{\circ} \mathrm{C}$. There were no significant differences in the number of cells in the embryos of the four treatment groups at 18, 24, and 36 hpf (Fig. 1f and i; Table 2). Because of the reduction in the size of the embryo cells as they proliferated, it was not possible to determine cell number after the 24-hpf stage; however, DAPI-stained nucleoli were visible in each nucleus, and counts of nucleoli were used as an index of differences in cell proliferation between treatment groups at that stage (Table 2). In the 48-hpf embryos, the Ct treatment group had significantly $(P<0 \cdot 05)$ more nucleoli compared with the controls (Table 2). In addition, whereas the $\mathrm{Ct}+\mathrm{RU}$ treatment group had significantly $(P<0 \cdot 05)$ more nucleoli than the control group (Con), there were no significant differences between the RU and the $\mathrm{Ct}+\mathrm{RU}$ treatment groups (Table 2).

Table 2 Effects of in ovo cortisol and RU486 treatments on the number of cells or nucleoli in 24-48 hpf embryos

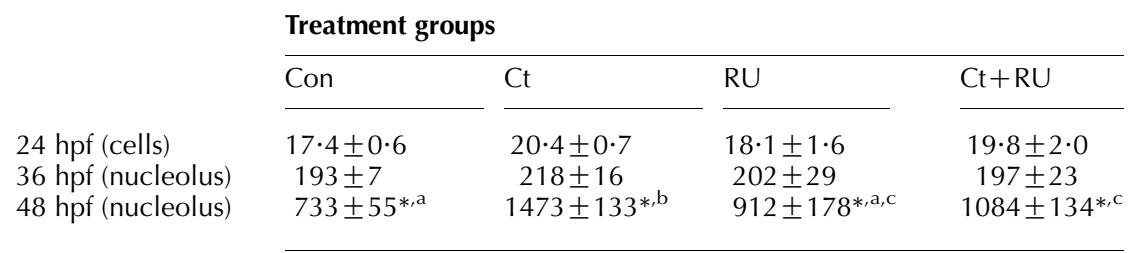

Data are shown as mean \pm S.E.M. $(n=4-5)$; means with similar lower case superscript letters within a row are not significantly different from one another at that embryo stage; asterisks indicate significant $(P<0 \cdot 01)$ differences from 36-hpf embryos within the same treatment group. 


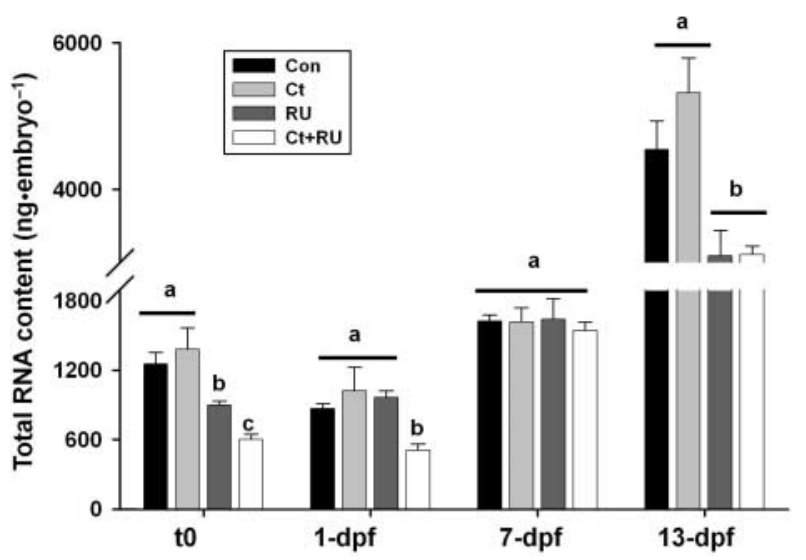

Figure 3 The effects of incubation of oocytes in ovarian fluid enriched with cortisol with and without RU486 on zygote and early total embryo RNA content (ng.embryo ${ }^{-1}$ ); t0 are freshly fertilized zygotes; 1, 7, and $13 \mathrm{dpf}$ represent the age of embryos. Data are shown as mean \pm S.E.M. $(n=4)$. Bars with similar subscript letters are not significantly different from one another within the same age group. See the text for differences between age groups.

The effects of cortisol and/or RU486 treatment of oocytes on the total RNA content of early embryos

In the eggs sampled immediately after fertilization $(\mathrm{t} 0)$, the total RNA contents of the eggs in the Con and Ct treatment groups were similar (Fig. 3), but in the values of the two RU486 treatment groups (RU and $\mathrm{Ct}+\mathrm{RU}$ ) were significantly lower $(P<0 \cdot 01)$ than those of the two non-RU486 treatment groups (Con and Ct; Fig. 3); moreover, the total RNA content of the $\mathrm{Ct}+\mathrm{RU}$ treatment group was significantly lower $(P<0.05)$ than that of the RU treatment group (Fig. 3).

By 7 dpf, total embryo RNA content had increased to levels that were significantly $(P<0 \cdot 05)$ higher compared with the 1-dpf embryos, but there were no significant differences among the treatment groups. The total embryo RNA contents at $13 \mathrm{dpf}$ for all treatment groups were significantly higher $(P<0.01)$ compared with newly fertilized eggs $(\mathrm{t} 0)$ and 1- and 7-dpf embryos (Fig. 3); in addition, the total RNA content of the two RU486 treatment groups (RU and $\mathrm{Ct}+\mathrm{RU}$ ) was significantly lower $(P<0 \cdot 05)$ than that of the Con and the Ct treatment groups (Fig. 3).

The effects of cortisol and/or RU486 treatment of oocytes on the relative expression of gr1 and gr 2 in embryos

In the t0 samples, the relative expression of $g r 1$ (ranging from $\sim 0.4$ to $\sim 1.2 \%)$ tended to be higher than that of $\mathrm{gr}^{2}$ (ranging from $\sim 0.09$ to $\sim 0.35 \%$; Fig. 4). However, as development proceeded, there was a decrease in the relative expression of $g r 1$ from to to $13 \mathrm{dpf}$, whereas the relative expression of $g r 2$ increased between 1 and $13 \mathrm{dpf}$ (Fig. 4).
In the $\mathrm{t} 0$ sample, the relative expression of both $g r 1$ and $g r 2$ was significantly lower $(P<0 \cdot 01)$ in the two RU486 treatment groups compared with the control and cortisol treatment groups (Fig. 4). Moreover, the expression level of $g r 2$ in the $\mathrm{Ct}+\mathrm{RU}$ treatment group was significantly lower $(P<0.05)$ than that of the RU treatment group (Fig. 4). Conversely, the relative expression of gr 1 in the Ct treatment group was significantly higher $(P<0.05)$ than that of the Con group (Fig. 4).

By $1 \mathrm{dpf}$, the expression levels of both $g r 1$ and $g r 2$ in the Con group had fallen significantly $(P<0 \cdot 05)$ relative to the t0 samples (Fig. 4). For gr1, there were no significant differences among treatments except for the $\mathrm{Ct}+\mathrm{RU}$ treatment group, which was significantly lower $(P<0.05$ or $P<0.01)$ than the other three treatment groups (Fig. 4). For gr2, the relative expression in the two cortisol-treated groups was significantly lower $(P<0 \cdot 01)$ than that in the two other groups (Fig. 4).

In both the 7- and 13-dpf embryos, there were no significant differences in the relative expression of $g r 1$ among the four treatment groups (Fig. 4). Conversely, for $g r 2$, the among-treatment pattern that was seen in the 1-dpf embryos was again evident in the 7-dpf embryos, but in a muted form, as the expression levels in all four treatment groups were increasing; the only significant differences $(P<0 \cdot 05)$ were between the Con and the two cortisol treatment groups (Ct and Ct+RU; Fig. 4). In the 13-dpf embryos, the pattern of relative expression of $g r 2$ among the four treatment groups was similar to that seen in the t0 samples, but the mean values were approximately tenfold higher in the 13-dpf embryos; the expression levels of the two groups reared from RU486-treated oocytes were significantly $(P<0 \cdot 01)$ lower than those of the two non-RU486-treated groups (Fig. 4).

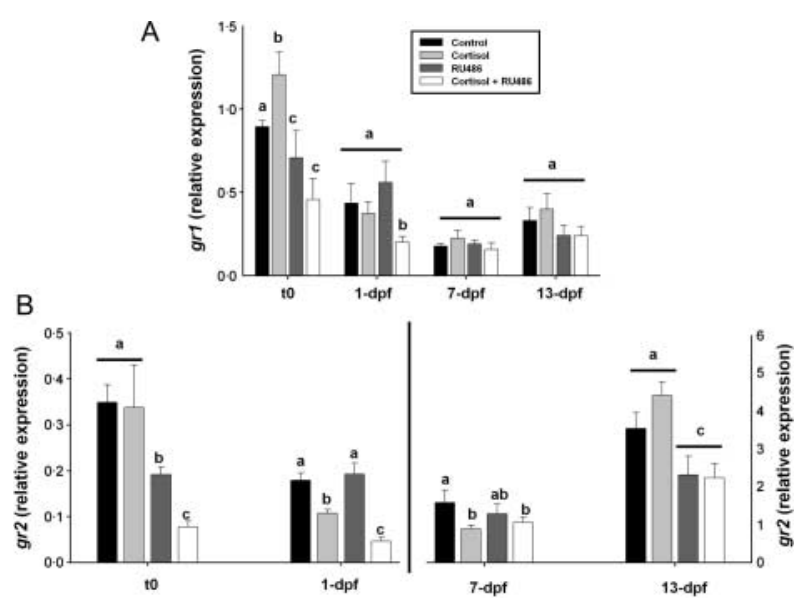

Figure 4 The effects of incubation of oocytes in ovarian fluid enriched with cortisol with and without RU486 on the relative expression of gr1 (A) and gr2 (B) by zygotes and early embryo. See the legend to Fig. 3. Data are shown as mean \pm S.E.M. $(n=4)$. Bars with similar subscript letters are not significantly different from one another. See the text for differences between age groups. 


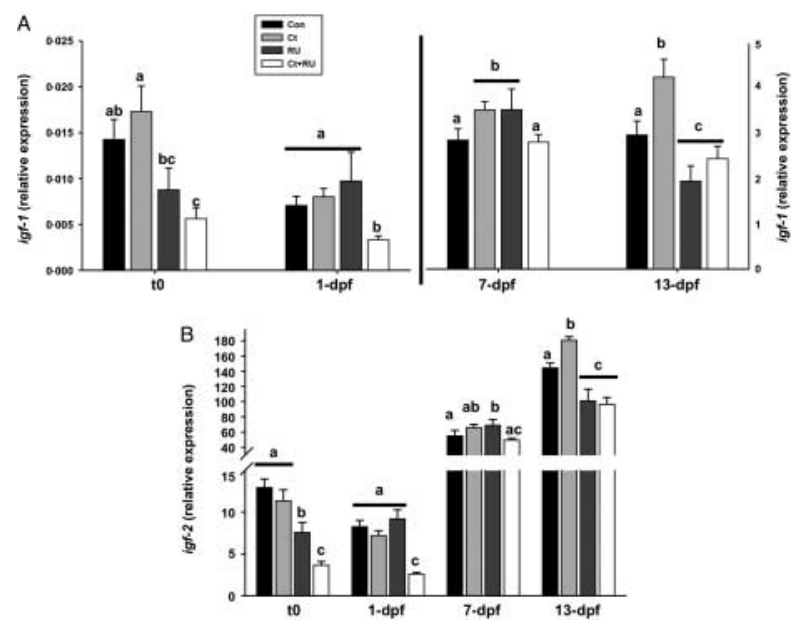

Figure 5 The effects of incubation of oocytes in ovarian fluid enriched with cortisol with and without RU486 on the relative expression of igf1 (A) and igf2 (B) by zygotes and early embryo. See the legend to Fig. 3. Data are shown as mean \pm s.E.M. $(n=4)$. Bars with similar subscript letters are not significantly different from one another. See the text for differences between age groups.

The effects of cortisol and/or RU486 treatment of oocytes on the relative expression of IGF system genes in embryos

Relative levels of igf 1 and igf 2 mRNA transcripts The relative abundance of igf $2 \mathrm{mRNA}$ was $\sim 20$ times more than that of igf1 mRNA at all developmental stages (Fig. 5A and $\mathrm{B})$. For both genes, the relative abundance of mRNA was significantly elevated $(P<0.05)$ in the 7 - and 13 -dpf embryos relative to the t0 eggs and 1-dpf embryos (Fig. 5A and B).

The relative expression of igf 1 in the to sample was similar in the Con and Ct treatment groups, and although the values for the two RU486 treatment groups tended to be lower than that for the non-RU486 treatment groups, only that of the $\mathrm{Ct}+\mathrm{RU}$ treatment group was significantly lower $(P<0 \cdot 01$; Fig. 5A). An expression pattern similar to that of igf 1 was found for igf 2 in the t0 sample, except that the two non-RU486 treatment groups were significantly higher $(P<0 \cdot 01)$ than both of the RU486 treatment groups (Fig. 5B).

The among-treatment pattern of the relative expression of igf1 and igf2 was similar (Fig. 5A and B). For igf1, the value in the $\mathrm{Ct}+\mathrm{RU}$ treatment group was significantly lower $(P<0 \cdot 05)$ than those of the two non-RU486 treatment groups, whereas for igf 2 , the value in the $\mathrm{Ct}+\mathrm{RU}$ treatment groups was significantly lower $(P<0 \cdot 01)$ than the values of the three other treatment groups (Fig. 5A and B).

By $7 \mathrm{dpf}$, the relative expression levels of the two genes were significantly higher $(P<0.05$ or $<0.01)$ than in the comparable treatment groups sampled at t0 and $1 \mathrm{dpf}$ (Fig. 5A and $\mathrm{B})$. For igf1, the in ovo cortisol treatment elicited a significant increase $(P<0.05)$ in the $\mathrm{Ct}$ treatment group relative to the Con group but a significant decrease $(P<0 \cdot 05)$ in the $\mathrm{Ct}+\mathrm{RU}$ treatment group relative to the $\mathrm{RU}$ treatment group (Fig. 5A and B).
The among-treatment relative expression of both the igf1 and the igf 2 genes in 13-dpf embryos exhibited a similar pattern, with a significantly higher $(P<0 \cdot 01)$ value in the Ct treatment group relative to the other three treatment groups and significantly lower $(P<0 \cdot 01)$ values for the RU and $\mathrm{Ct}+\mathrm{RU}$ treatment groups than the embryos reared from oocytes that had not been incubated with RU486 (Fig. 5A and B).

The effects of cortisol and/or RU486 treatment of oocytes on the relative expression of igf-rIa and igf-r $1 \mathrm{~b}$ genes

The relative levels of mRNA encoding for igf-rIb were $>50$-fold more than those for igf-rIa in the t0 eggs and 1 -dpf embryos (Fig. 6A and B). However, the expression levels of the two genes were essentially similar from 1- to 13-dpf embryos (Fig. 6A and B). The overall relative expression levels of igf-rIa in the t0 and 1-dpf stages were in the same range; there were $\sim 7 \cdot 5$ - and $\sim 20 \cdot 0$-fold increases in the expression levels between these stages and 7- and 13-dpf embryos respectively; these increases were significantly different $(P<0 \cdot 01)$ for all treatment groups at each stage $(\mathrm{t} 0 / 1$, $<7$, and $<13$ dpf; Fig. 6A). The relative expression of igf-rlb was in a similar range at all the developmental stages examined (Fig. 6B).

At the $\mathrm{t} 0$ stage, the among-treatment pattern of the relative expression of igf-rIa and igf-Ib was essentially similar, with significantly lower $(P<0 \cdot 01)$ values evident in the $\mathrm{Ct}+\mathrm{RU}$ treatment group compared with the other three treatment groups (Fig. 6A and B). In the case of igf-rIa, the values were not significantly different in the Con, $\mathrm{Ct}$, and RU treatment groups (Fig. 6A), whereas for igf-rIb, the Con, Ct, and RU treatment groups differed significantly $(P<0 \cdot 05)$ from one another $(\mathrm{Ct}>\mathrm{Con}>\mathrm{RU}$; Fig. 6B).

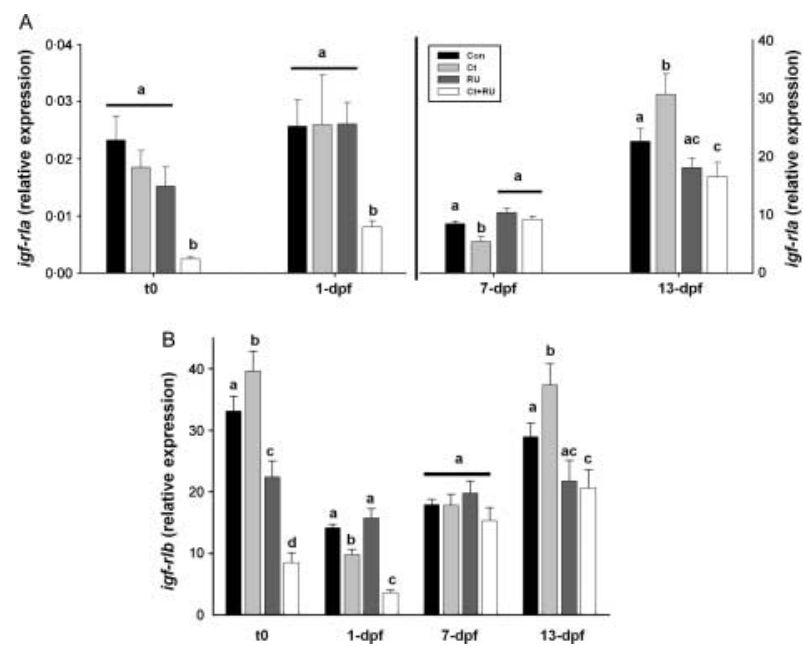

Figure 6 The effects of incubation of oocytes in ovarian fluid enriched with cortisol with and without RU486 on the relative expression of igf-rla (A) and igf-rlb (B) by zygotes and early embryo. See the legend to Fig. 3. Data are shown as mean \pm s.E.M. $(n=4)$. Bars with similar subscript letters are not significantly different from one another. See the text for differences between age groups. 
Table 3 The effects of in ovo cortisol and RU486 treatment on the correlation between the expressions of igf system genes and gr genes in 7-days post-fertilization (dpf) embryos

Treatment groups

\begin{tabular}{|c|c|c|c|c|c|c|c|c|}
\hline & \multicolumn{2}{|c|}{ Con } & \multicolumn{2}{|c|}{$\mathrm{Ct}$} & \multicolumn{2}{|c|}{$\mathrm{RU}$} & \multicolumn{2}{|c|}{$\mathrm{Ct}+\mathrm{RU}$} \\
\hline & gr1 & gr2 & gr1 & gr2 & gr1 & $g r 2$ & gr1 & $g r 2$ \\
\hline $\begin{array}{l}\text { igf1 } \\
\text { igf2 }\end{array}$ & $\begin{array}{l}+0.20 \\
+0.69^{+}\end{array}$ & $\begin{array}{l}+0 \cdot 19 \\
+0.74^{+}\end{array}$ & $\begin{array}{l}+0 \cdot 06 \\
+0 \cdot 40^{\ddagger}\end{array}$ & 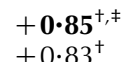 & $\begin{array}{l}+0 \cdot 20 \\
+\mathbf{0} \cdot 01^{\ddagger}\end{array}$ & $\begin{array}{l}+\mathbf{0} \cdot 60^{*, \neq} \\
+0 \cdot 85^{+}\end{array}$ & $\begin{array}{l}+0 \cdot 33 \\
+\mathbf{0} \cdot \mathbf{9}^{\ddagger}\end{array}$ & $\begin{array}{l}+\mathbf{0} \cdot \mathbf{9 5}^{+,} \\
+0.92^{+}\end{array}$ \\
\hline igf-rla & +0.02 & $+0 \cdot 14$ & -0.07 & $+0.91^{\dagger, \neq}$ & $-0 \cdot 57^{*, \neq}$ & $+0 \cdot 12$ & -0.37 & $+0.97^{+,}$ \\
\hline igf-rlb & $+0 \cdot 69^{+}$ & $+0.56^{+}$ & $+0 \cdot 46^{\ddagger}$ & $+0.63^{+}$ & $+0 \cdot 41^{\ddagger}$ & $+0.94^{+}$ & $-0 \cdot 12^{\ddagger}$ & $+0.91^{+}$ \\
\hline
\end{tabular}

$R$ values are shown $(n=16)$; significances $\left({ }^{*} P<0.05\right.$ or ${ }^{\dagger} P<0 \cdot 01$ respectively) correlations. $R$ values shown in bold and marked ' $₹$ ' are correlation results that differ from the control treatment group (Con).

Among the 1-dpf embryos, the relative expression of igf-rIa in the $\mathrm{Ct}+\mathrm{RU}$ treatment group was significantly lower $(P<0 \cdot 01)$ than in the other three groups, which did not differ significantly from one another (Fig. 6A). In the same age group, the relative expression of igf-r $r b$ in both the $\mathrm{Ct}$ and the $\mathrm{Ct}+\mathrm{RU}$ treatment groups was significantly $(P<0 \cdot 05)$ lower than that in the Con and RU treatment groups (Fig. 6B). In the 7-dpf embryos, the relative expression of igf-rIa was significantly lower $(P<0.05)$ in the $\mathrm{Ct}$ treatment group relative to the three other treatment groups, which had similar values (Fig. 6A); for igf-rIb, there were no significant differences in the relative expression of the gene among the four treatment groups (Fig. 6B).

By $13 \mathrm{dpf}$, a similar among-treatment pattern of expression was found for both igf-rIa and igf-rIb; the values in the $\mathrm{Ct}$ treatment group were significantly higher $(P<0 \cdot 05)$ than those in the other three groups, and the value in the $\mathrm{Ct}+\mathrm{RU}$ treatment group was significantly lower $(P<0 \cdot 05)$ than that in the Con group (Fig. 6A and B).

The effects of cortisol and/or RU486 treatment of oocytes on the correlations between the relative expression of gr 1 and gr 2 and several IGF system genes in 7-dpf embryos

The $R$ values of the correlation analyses of specific genes are shown in Table 3; the values shown in bold indicate different correlation outcomes for either gr1 or gr2 correlations with other genes than were found in the Con group. The findings can be summarized as follows: a) The expression of gr1 was significantly correlated $(P<0 \cdot 01)$ with the expression of igf 1 in the Con group, but this correlation was not found in the other three treatment groups; b) the expression of $g r 1$ was significantly correlated $(P<0 \cdot 01)$ with the expression of igf-rIb in the Con group, but this correlation was not found in the other three treatment groups; c) there was no correlation between the expression of gr 1 and igf-rIa in the Con group, but a significant negative correlation $(P<0 \cdot 05)$ was found in the RU treatment group; d) there was no correlation between the expression of $g r 2$ and igf 1 in the Con group, but significant correlations were found in the Ct $(P<0 \cdot 01)$, RU $(P<0 \cdot 05)$, and $\mathrm{Ct}+\mathrm{RU}(P<0 \cdot 01)$ treatment groups; and e) there was no correlation between the expression of gr2 and igf-rIa in the Con group, but significant correlations $(P<0 \cdot 01)$ were found in the Ct and $\mathrm{Ct}+\mathrm{RU}(P<0 \cdot 01)$ treatment groups.

\section{Discussion}

Because of the practical limitations imposed by the necessity to pool oocytes from several fish before the prefertilization incubations of oocyte treatment groups (described in detail in the Materials and Methods section), the experimental design did not permit within-treatment random replication. Consequently, it was not possible to estimate accurately within a single reproductive period the biological variation of the population in response to the various treatments. However, as indicated in the Materials and Methods section, with the exception of the measurements of total RNA and gene expression, the remaining parameters were examined over more than one reproductive season, with similar patterns of among-treatment responses.

The patterns of responses to the various treatments found in this study argue strongly for a role for GRs during zygotic activation and the expression of growth-related genes during early embryogenesis in rainbow trout. These observations support our previous findings showing that increasing the cortisol content of rainbow trout oocytes from $\sim 3$ ng. oocyte ${ }^{-1}$ (untreated oocytes) to $\sim 5$ ng.oocyte ${ }^{-1}$ significantly enhanced the growth of the embryos reared from these oocytes ( $\mathrm{Li}$ et al. 2010). In addition, the expression of igf 1 in the zygote and embryos between $1-$ and 21-dpf and igf2 in 21-dpf embryos was enhanced (Li et al. 2010). This study provided evidence that suggests a key role for GR in the modulation of growth, possibly via changes in the expression of several IGF system-related genes, including both the genes that encode for the peptide hormones, IGF1 and 2, and their protein receptors. An important component of the study was the use of the progesterone receptor (PR) and GR antagonist, RU486 (mifepristone), which has been used previously for the evaluation of GR function in fish and mammals (Vijayan et al. 1994, Pariante et al. 2001, Aluru et al. 2004, Scott et al. 2005, Veillette et al. 2007, Vizzini et al. 2007, Peeters et al. 2008, Du et al. 2009, Alderman et al. 2012). 
The antagonistic properties of RU486 on PRs and GRs are complex and still not fully understood; the PR antagonistic action of RU486 has received most attention (reviewed by Leonhardt \& Edwards (2002)). RU486 appears to interact with the receptors at several levels of the ligand-receptorgene activation/repression process. These include some nonexclusive competitive interaction with the receptor ligand binding domain (LBD), enhanced dimerization of the receptor protein, an increased bonding of the dimer with the DNA hormone response elements in the promoter regions of responsive genes, inhibition of co-activator recruitment, interference with the direct interaction of receptors with proteins involved in gene transcription, and impaired interaction of the receptor protein with several other transcriptional factors. Moreover, different isoforms of the receptor have differing affinities for and interactions with RU486 (Leonhardt \& Edwards 2002, Bury et al. 2003). Consequently, tissue and species variability in the responses to RU486 may also be a factor. Thus, interpretation of the responses of the embryonic cells to complex and partial antagonists such as RU486 needs to be made with caution; however, as discussed below, in this study, several of the responses to cortisol were curtailed if the oocytes were co-incubated with RU486, suggesting that cortisol was exerting at least some of its actions via an interaction with GR. Notwithstanding, as will be discussed below, some of the observed effects of RU486 with regard to the suppression of maternal mRNA transcripts cannot be attributed to its GR antagonistic properties.

There were clear interactions of cortisol with GR proteins during zygote activation after fertilization at $2 \mathrm{hpf}$, whereby the glucocorticoid appeared to mediate the movement of GR toward the nucleus in the two cortisol-treated groups of zygotes (with and without co-incubation with RU486; Fig. 2). Interestingly, despite the presence of $\sim 3.5 \mathrm{ng}$ per organism of cortisol in the Con zygotes, there was no such GR translocation evident as might be expected (Fig. 2). This observation suggests that there may be an intracellular threshold cortisol level for the activation of GR; however, a more likely explanation relates to the amount of cortisol that is 'accessible' to GR in the zygote and blastomeres. Although the intracellular distribution of the glucocorticoid in the oocyte and zygote is not known, it is likely that a major fraction is associated with the lipid-rich content of the cytoplasmic vesicles, rather than in solution in the aqueous medium of the ooplasm. If this is the case, the cortisol concentration in the aqueous medium of the Con oocytes may not have been sufficient to activate the GR; conversely, following the incubation of the oocytes in cortisol-enriched ovarian fluid, the aqueous cortisol component may have been sufficient to facilitate GR activation. Further, the absence of GR translocation in the Con zygotes also suggests that the translocation that was observed in this study was probably not part of the range of post-fertilization molecular migratory events involved in the relocation of ooplasm organelles toward the animal pole.
In this study, there was no evidence of either an inhibitory or stimulatory effect of RU486 on GR translocation (Fig. 2), which suggests that the binding of RU486 to the GR protein does not bring about translocation in the rainbow trout zygote as it appears to do in several mammalian cell lines (murine fibroblast cells: Pariante et al. (2001), primate kidney and osteosarcoma cells: Lewis-Tuffin et al. (2007), and murine pituitary cells: Peeters et al. (2008) and Spiga et al. (2011)). Moreover, RU486 does not appear to inhibit cortisolactivated translocation. It is thus possible that if RU486 does associate with the salmonid GR LBD, it does not activate the receptor, as it appears to do in mammals. This argument is supported by the observation that RU486 on its own did not significantly enhance cell numbers (relative to the controls) during the 48-hpf period, whereas in the $\mathrm{Ct}$ and $\mathrm{Ct}+\mathrm{RU}$ treatment groups, there was a significant increase in cell numbers (Table 2); these findings suggest that cortisol acting as the ligand for GR elicited this increased cell proliferation at a very early stage in embryogenesis. The apparent absence of a GR translocation response to RU486 might be that the RU486-associated GR is not recognized by the antiserum, but since RU486 did not appear to decrease the GR immunofluorescence signal, the absence of a response was not a decrease in antigenicity. The observations presented herein suggest actions of the GR antagonist that are currently not defined; whether these are related to GR protein degradation (Alderman et al. 2012), affecting intracellular GR levels and thus reducing the extent of agonistic actions of RU486 (Zang et al. 2007), the agonism of RU486 for GR being affected by competition with other receptors (Hawkins \& Thomas 2010), has yet to be determined.

An interesting and unanticipated finding was the apparent partial suppression of the total RNA content of the zygotes (t0) following the in ovo RU486 treatment (Fig. 3). Evidence of an inhibition of RNA synthesis by RU486 was less pronounced in the 1-dpf embryos and not found in the 7-dpf embryos; however, the effect was again evident in the 13-dpf embryos, in which the total RNA content of the two RU486-treated groups was significantly lower $(P<0 \cdot 01)$ than that of the Con and $\mathrm{Ct}$ treatment groups (Fig. 3). Because the total RNA measurements include both coding and noncoding RNA, the relative composition of coding vs noncoding RNA is not known; however, the apparent loss of the suppressive action of RU486 on total RNA during the transition from the zygotic to embryonic genome and reappearance of RU486 suppression when the embryonic genome is established may reflect a broad-based regulatory role for glucocorticoids in RNA synthesis. As for other findings, it suggests that nongenomic programming occurs in the zygote in response to the presence of RU486 and that the programming of the one-time exposure to RU486 is still in effect during early embryonic genome expression, an indicator of the plasticity of the epigenomic response to environmental influences (in this case, the presence of a GR antagonist) during early development. 
The among-treatment patterns of the relative abundance of mRNA transcripts of the six genes considered in this study in the t0 samples (Figs 4, 5 and 6) suggest that RU486 may destabilize components of the zygotic transcriptome. It is not clear at this point how that may occur, and it would appear to contradict the currently held view that the zygotic transcriptome is relatively stable and necessary for the regulation of the first cell division. However, there is evidence in several species for differential destabilization of a subset of mRNAs (Bashirulla et al. 1999, 2001, Tandros et al. 2003, 2007, Ferg et al. 2007, Shiokawa et al. 2008, Tandros \& Lipshitz 2009). Therefore, the data presented in this paper may reflect an involvement of RU486 in destabilizing of some components of the zygotic transcriptome. Of significance was the evidence of a reoccurrence of the suppressive action of RU486 on the transcriptome of 13-dpf embryos: gr2, igf1, igf2, igf-rIb, and to a lesser extent, igf-rIa (Figs 4, 5 and 6) were significantly affected, and only gr 2 mRNA transcript abundance, which was very low in all treatment groups in both 7- and 13-dpf embryos, was not affected by RU486 treatment (Fig. 4). Furthermore, co-incubation of oocytes with a combination of RU486 and cortisol did not overturn the suppressive action of RU486 on the transcriptome. On the contrary, the relative abundance of mRNA encoding for $g r 2$, igf2, igf-rla, and igf-rlb in the $\mathrm{Ct}+\mathrm{RU}$ treatment group of zygotes was significantly $(P<0 \cdot 05)$ lower than those of the RU treatment group (Figs 4, 5 and 6); there were no significant differences between these two treatment groups for any of the genes of interest in the 13-dpf embryos (Figs 4, 5 and 6). These data are suggestive of an initial suppressive action of cortisol, compounding the suppressive action of the GR antagonist, and a loss of that additional action of cortisol by the 13-dpf stage of embryo development. However, comparisons of the Con and Ct treatment groups showed a stimulatory action of cortisol on the expression of the four IGF-related genes in the 13-dpf embryos (Figs 5 and 6). Thus, in the absence of the GR antagonist, cortisol stimulates the relative expression of these genes, but in the presence of the GR antagonist, gene expression is suppressed relative to the control and may be suppressed further by the concerted actions of RU486 and cortisol.

The information obtained from the multiple correlation analysis of the relative expression of $g r 1$ and $g r 2$ and the IGF system genes in the 7-dpf embryos provided additional indications of complex interactions between these genes during the critical period of transition from the influence of the zygotic genome to that of the embryonic genome (and epigenome). In the Con treatment group, there were significant $(P<0 \cdot 01)$ direct correlations between the relative expression of both $g r 1$ and $g r 2$ with the relative expression of igf 2 and igf-rIb (Table 3), suggesting a link between the two systems. Moreover, the significant correlations (or lack thereof) between the relative expression of $g r 1$ and $g r 2$ with other genes that were evident in the Con treatment group were radically changed in the three other treatment groups (Table 3). Specifically, the relationships between the relative expression of $g r 1$ and igf2, igf-rIa and igf-rIb were changed, as were the relationships between $g r 2$ and igf1, igf2 and igf-rIa (Table 3). Taken together, these observations support the hypothesis of a complex interaction between the GR and IGF system, one that is sensitive to changes in cortisol levels and the altered status of the GR (as brought about by the presence of the GR antagonist).

The dynamic developmental processes of embryogenesis involve extremely complex and highly coordinated cell proliferation and growth, cellular migration, and apoptosis. Some of these processes have been shown to be influenced by IGF signaling (Wood et al. 2005, Huang et al. 2007, Schlueter et al. 2007, Reinecke 2010). The growth promoting effects of cortisol on embryonic cell proliferation and embryo growth in this study (Table 2), together with the changes in the expression of IGF system gene expressions in early embryos (Figs 5 and 6), are consistent with the proposition that cortisol activates the IGF system signaling pathway in early embryonic cells. IGF system activation may then contribute to the promotion of early embryonic cell proliferation and embryonic growth. In post-embryonic fish, cortisol-activated stimulation of the expression of IGF- and GH system-related genes has been described in Mozambique tilapia (Oreochromis mossambicus) ovarian follicles (Huang et al. 2007), hepatocytes (Pierce et al. 2011), and rainbow trout lymphocytes (Yada et al. 2005). In mammalian embryos, the role of GR activation in cellular maturation and growth, most notably stem cell differentiation, is well established (Derfoul et al. 2006, Phillips et al. 2006, Mikami et al. 2008, Stewart et al. 2008). Similarly, GR has been associated with the regulation of some aspects of the development of ovine cardiomyocytes (Giraud et al. 2006) and the complex patterns of expression of myogenic genes in zebrafish (Danio rerio; Nesan et al. 2012). These and other studies demonstrate that cortisol plays numerous biological functions by interactions with multiple cellular signaling pathways, that include, but are not limited to, the direct transcription factor actions of cortisol-activated GR on target genes. These interactions are still imperfectly understood, as is the mode of action of cortisol during prenatal stressor-related epigenomic programming (reviewed by Phillips (2007), Gluckman et al. (2009), Godfrey et al. (2010) and Hochberg et al. (2011)).

In summary, a one-time in ovo exposure to cortisol by immersion of rainbow trout oocytes, before fertilization, in cortisol-enriched ovarian fluid had lasting effects on the growth characteristics of the embryo and juvenile progeny (Li et al. 2010). This study demonstrated that at least some of these effects are related to multiple and complex interactions between GR activation of changes in the expression of IGF system genes. The studies also point to novel actions of cortisol that cannot be explained on the basis of the currently understood modes of action and roles of the glucocorticoids. Similarly, the studies also provide evidence of an action of the RU486 GR antagonist on the destabilization of maternal mRNA transcripts. 


\section{Declaration of interest}

The authors declare that there is no conflict of interest that could be perceived as prejudicing the impartiality of the research reported.

\section{Funding}

The work was supported by Discovery Grants from the National Science and Engineering Research (NSERC) Council of Canada and by funding from the Ontario Ministry of Agriculture and Food. M L was supported by an NSERC Doctoral Scholarship.

\section{Acknowledgements}

The authors express their sincere appreciation to the professional staff at the Alma Aquaculture Research Station for their assistance with the animal experimentation component of the study.

\section{References}

Alderman SL, McGuire A, Bernier NJ \& Vijayan MM 2012 Central and peripheral glucocorticoid receptors are involved in the plasma cortisol response to an acute stressor in rainbow trout. General and Comparative Endocrinology 176 79-85. (doi:10.1016/j.ygcen.2011.12.031)

Aluru N, Jorgensen EH, Maule AG \& Vijayan MM 2004 PCB disruption of the hypothalamus-pituitary-interrenal axis involves brain glucocorticoid receptor downregulation in anadromous Arctic charr. American Journal of Physiology. Regulatory, Integrative and Comparative Physiology 287 R 787-R793. (doi:10.1152/ajpregu.00091.2004)

Aluru N, Leatherland JF \& Vijayan MM 2010 Bisphenol A in oocytes leads to growth suppression and altered stress performance in juvenile rainbow trout. PLoS One 5 e10741. (doi:10.1371/journal.pone.0010741)

Bahrekazemi M, Matinfar A, Soltani M, Abtahi B, Pusti I \& Mohagheghi A 2009 The relation between egg viability, selected aspects of egg and ovarian fluid composition and time of stripping in endangered Caspian brown trout (Salmo trutta caspius). Journal of Fisheries and Aquatic Science 4 306-315. (doi:10.3923/jfas.2009.306.315)

Barry TP, Malison JA, Held JA \& Parrish JJ 1995 Ontogeny of the cortisol stress response in larval rainbow trout. General and Comparative Endocrinology 97 57-65. (doi:10.1006/gcen.1995.1006)

Bashirulla A, Cooperstock RL \& Lipshitz HD 2001 Spatial and temporal control of RNA stability. PNAS 98 7025-7028. (doi:10.1073/pnas. 111145698)

Bashirulla A, Halsell SR, Cooperstock RL, Kloc M, Karaiskakis A, Fisher WW, Fu W, Hamilton JK, Etkin LD \& Lipshitz HD 1999 Joint action of two RNA degradation pathways controls the timing of maternal transcript elimination at the midblastula transition in Drosophila melanogaster. EMBO Journal 18 2610-2620. (doi:10.1093/emboj/18.9.2610)

Bury NR, Sturn A, Le Rouzic P, Lethimonier C, Ducouret B, Guiguen Y, Robinson-Rechavi MK, Laudet V, Rafestin-Oblin ME \& Prunet P 2003 Evidence for two distinct functional glucocorticoid receptors in teleost fish. Journal of Molecular Endocrinology 31 141-156. (doi:10.1677/jme.0.0310141)

Derfoul A, Perkings GL, Hall DJ \& Tuan RS 2006 Glucocorticoids promote chondrogenic differentiation of adult human mesenchymal stem cell by enhancing expression of cartilage extracellular matrix genes. Stem Cells 24 1487-1495. (doi:10.1634/stemcells.2005-0415)

Du J, Wang Y, Hunter R, Wei Y, Blumenthal R, Falke C, Khairova R, Zhou R, Yuan P, Machado-Vieira M et al. 2009 Dynamic regulation of mitochondrial function by glucocorticoids. PNAS 106 3543-3548. (doi:10.1073/pnas.0812671106)

Eriksen MS, Bakken M, Espmark A, Braastad BO \& Salte R 2006 Prespawning stress in farmed Atlantic salmon Salmo salar: maternal cortisol exposure and hyperthermia during embryonic development affect offspring survival, growth and incidence of malformations. Journal of Fish Biology $\mathbf{6 9}$ 114-129. (doi:10.1111/j.1095-8649.2006.01071.x)

Eriksen MS, Espmark A, Braastad BO, Salte R \& Bakken M 2007 Long-term effects of maternal cortisol exposure and mild hyperthermia during embryogeny on survival, growth and morphological anomalies in farmed Atlantic salmon Salmo salar offspring. Journal of Fish Biology 70 462-473. (doi:10.1111/j.1095-8649.2007.01317.x)

Eriksen MS, Kittilsen FG, McCormick S \& Damsgård MI 2011 Stressed mothers - troubled offspring: a study of behavioural maternal effects in farmed Salmo salar. Journal of Fish Biology 79 575-586. (doi:10.1111/j.10958649.2011.03036.x)

Ferg M, Sanges R, Gehrig J, Kiss J, Bauer M, Lovas A, Szabo M, Yang L, Straehle U, Pankratz MJ, Olasz F, Stupka E \& Muller F 2007 The TATA-binding protein regulates maternal mRNA degradation and differential zygotic transcription in zebrafish. EMBO Journal 26 3945-3956. (doi:10.1038/sj.emboj.7601821)

Fitzsimons CP, Ahmed S, Wittevrongel CF, Schouten TG, Dijkmans TF, Scheenen WJ, Schaaf MJ, de Kloet ER \& Vreugdenhil E 2008 The microtubule-associated protein doublecortin-like regulates the transport of the glucocorticoid receptor in neuronal progenitor cells. Molecular Endocrinology 22 248-262. (doi:10.1210/me.2007-0233)

Giraud GD, Louey S, Jonker S, Schultz J \& Thomburg KL 2006 Cortisol stimulates cell cycle activity in the cardiomyocyte of the sheep fetus. Endocrinology 147 3643-3649. (doi:10.1210/en.2006-0061)

Gluckman PD, Hanson MA, Buklijas T, Low FM \& Beedle AS 2009 Epigenetic mechanisms that underpin metabolic and cardiovascular diseases. Nature Reviews. Endocrinology 5 401-408. (doi:10.1038/nrendo. 2009.102)

Godfrey KM, Gluckman PD \& Hanson MA 2010 Developmental origins of metabolic disease: life course and intergenerational perspectives. Trends in Endocrinology and Metabolism 21 199-205. (doi:10.1016/j.tem.2009.12.008)

Gravel A \& Vijayan MM 2006 Salicylate disrupts interrenal steroidogenesis and brain glucocorticoid receptor expression in rainbow trout. Toxicological Sciences 93 41-49. (doi:10.1093/toxsci/kfj166)

Hawkins MB \& Thomas P 2010 The unusual binding properties of the third distinct teleost estrogen receptor subtype ER $\beta$ a are accompanied by highly conserved amino acid changes in the ligand binding domain. Endocrinology 145 2968-2977. (doi:10.1210/en.2003-0806)

Hayashi Y, Kobira H, Yamaguchi T, Shiraishi E, Yazawa T, Hirai T, Kamei Y \& Kitano T 2010 High temperature causes masculinization of genetically female medaka by elevation of cortisol. Molecular Reproduction and Development 77 679-686. (doi:10.1002/mrd.21203)

Heitzer MD, Wolf IM, Sanchez ER, Witchel SF \& DeFranco DB 2007 Glucocorticoid receptor physiology. Reviews in Endocrine \& Metabolic Disorders 8 321-330. (doi:10.1007/s11154-007-9059-8)

Hochberg Z, Feil R, Constancia M, Fraga M, Junien C, Carel JC, Boileau P, Lillycrop K, Scharfmann R, Sheppard A et al. 2011 Child health, developmental plasticity, and epigenetic programming. Endocrine Reviews 32 159-224. (doi:10.1210/er.2009-0039)

Huang WT, Yu HC, Hsu CC, Liao CF, Gong HY, Lin CJ, Wu JL \& Weng CF 2007 Steroid hormone (17 $\beta$-estradiol and hydrocortisone) upregulate hepatocyte nuclear factor (HNF)-3 $\beta$ and insulin-like growth factors I and II expression in the gonads of tilapia (Oreochromis mossambicus) in vitro. Theriogenology 68 988-1002. (doi:10.1016/j.theriogenology.2007.07.016)

Lahnsteiner F 2000 Morphological, physiological and biochemical parameters characterizing over-ripening of rainbow trout eggs. Fish Physiology and Biochemistry 23 107-118. (doi:10.1023/A:1007839023540)

Leatherland JF 2010 Endocrine and reproductive system, including their interaction with the immune system. In: Fish Diseases and Disorders. Volume 2, Non-Infectious Disorders, 2nd edn, pp 85-143. Eds JF Leatherland \& PTK Woo. New York: CABI Publishing.

Leatherland JF, Ferris J \& Li M 2012 Comparison of the affect of stress on ovarian function, reproduction and neonatal outcomes in fish and mammals: possible mechanisms of action. In The Physiology of Stress. Eds SE Wendelaar Bonga, S Peter \& B Peter. New York: Springer (In press). 
Leatherland JF, Li M \& Barkataki S 2010 Stressors, glucocorticoids and ovarian function in teleosts. Journal of Fish Biology 76 86-111. (doi:10.1111/j.10958649.2009.02514.x)

Leonhardt SA \& Edwards DP 2002 Mechanism of action of progesterone antagonists. Experimental Biology and Medicine 227 969-980.

Lewis-Tuffin LJ, Jewell CM, Bienstock RJ, Collins JB \& Cidlowski JA 2007 Human glucocorticoid receptor $\beta$ binds RU-486 and is transcriptionally active. Molecular and Cellular Biology 27 2266-2282. (doi:10.1128/MCB. 01439-06)

Li M 2011. The actions of cortisol on rainbowtrout (Oncorhynchus mykiss) early embryo developmental biology. PhD Dissertation. University of Guelph. Canada (http://search.proquest.com/docview/883529121/ PDF).

Li M, Bureau D, King WA \& Leatherland JF 2010 The actions of in ovo cortisol on egg fertility, embryo development and the expression of growthrelated genes in rainbow trout embryos, and the growth performance of juveniles. Molecular Reproduction and Development 77 922-931. (doi:10.1002/mrd.21239)

Li M \& Leatherland JF 2008 Temperature and ration level effect on rainbow trout embryo IGF system components and growth performance. General and Comparative Endocrinology 155 668-697. (doi:10.1016/j.ygcen. 2007.08.017)

Li M, Raine JC \& Leatherland JF 2007 Expression profiles of growth-related genes during the very early development of rainbow trout embryos reared at two incubation temperatures. General and Comparative Endocrinology 153 302-310. (doi:10.1016/j.ygcen.2007.02.012)

Li M, Russell S, Lumsden JS \& Leatherland JF 2011 The influence of oocyte cortisol on the early ontogeny of intelectin and TLR-5, and changes in lysozyme activity in rainbow trout (Oncorhynchus mykiss) embryos. Comparative Biochemistry and Physiology 160B 159-165. (doi:10.1016/ j.cbpb2011.08.002)

Madan P, Rose K \& Watson AJ 2007 Na/K-ATPase $\beta 1$ subunit expression is required for blastocyst formation and normal assembly of trophectoderm tight junction associated proteins. Journal of Biological Chemistry 282 12127-12134. (doi:10.1074/jbc.M700696200)

Matthews SG \& Phillips DIW 2010 Transgenerational inheritance of the stress response: a new frontier in stress research. Endocrinology 151 7-13. (doi:10.1210/en.2009-0916)

Mikami Y, Takahashi T, Kato S \& Takagi M 2008 Dexamethasone promotes DMP1 mRNA expression by inhibiting negative regulation of Runx2 in multipotential mesenchymal progenitor. Cell Biology International 32 239-246. (doi:10.1016/j.cellbi.2007.08.033)

Milla S, Jalabert B, Rime H, Prunet P \& Bobe J 2006 Hydration of rainbow trout oocyte during meiotic maturation and in vitro regulation by 17,20ß-dihydroxy-4-pregnen-3-one and cortisol. Journal of Experimental Biology 209 1147-1156. (doi:10.1242/jeb.02094)

Milla S, Wang N, Mandiki SNM \& Kestemont P 2009 Corticosteroids: friends or foes of teleost fish reproduction. Comparative Biochemistry and Physiology 153A 242-251.

Nesan D, Kamkar M, Burrows J, Scott IC, Marsden M \& Vijayan MM 2012 Glucocorticoid receptor signalling is essential for mesoderm formation and muscle development in zebrafish. Endocrinology 153 1288-1300 (doi:10.1210/en.2011-1559). (doi:10.1210/en.2011-1559)

Pariante CM, Pearce BD, Pisell TL, Su C \& Miller AH 2001 The steroid receptor antagonist RU40555 and RU486 activate glucocorticoid receptor translocation and are not excreted by the steroid hormones transporter in L929 cells. Journal of Endocrinology 169 309-320. (doi:10.1677/joe.0. 1690309)

Peeters BW, Ruigt GSF, Craighead M \& Kitchener P 2008 Differential effects of the new glucocorticoid receptor agonist ORG 34517 and RU486 (Mifepristone) on glucocorticoid receptor nuclear translocation in the AtT20 cell line. Annals of the New York Academy of Sciences 1148 536-541. (doi:10.1196/annals.1410.072)

Pfaffl MW, Tichopad A, Prgomet C \& Neuvians TP 2004 Determination of stable housekeeping genes, differentially regulated target genes and sample integrity: BestKeeper - Excel-based tool using pair-wise correlations. Biotechnology Letters 26 509-515. (doi:10.1023/B:BILE. 0000019559.84305.47)
Phillips DIW 2007 Programming of the stress response: a fundamental mechanism underlying the long-term effects of the fetal environment. Journal of Internal Medicine 261 453-460. (doi:10.1111/j.1365-2796.2007. 01801.x)

Phillips JE, Gersbach CA, Wojtowicz AM \& García AJ 2006 Glucocorticoidinduced osteogenesis is negatively regulated by Runx $2 / \mathrm{Cbfa} 1$ serine phosphorylation. Journal of Cell Science 119 581-591. (doi:10.1242/jcs. 02758)

Pierce AL, Breves JP, Moriyama S, Hirano T \& Grau EG 2011 Differential regulation of igf1 and igf 2 mRNA levels in tilapia hepatocytes: effects of insulin and cortisol on GH sensitivity. Journal of Endocrinology 211 201-210. (doi:10.1530/JOE-10-0456)

Raine JC, Cameron C, Vijayan MM, LaMarre J \& Leatherland JF 2004 The effect of elevated oocytes triiodothyronine content on development of rainbow trout embryos and the expression of mRNA encoding for thyroid hormone receptors. Journal of Fish Biology 65 206-226. (doi:10.1111/ j.0022-1112.2004.00445.x)

Reinecke M 2010 Insulin-like growth factor and fish reproduction. Biology of Reproduction 82 656-661. (doi:10.1095/biolreprod.109.080093)

Sampath-Kumar R, Byers RE, Munro AD \& Lam TJ 1995 Profile of cortisol during the ontogeny of the Asian seabass, Lates calcarifer. Aquaculture $\mathbf{1 3 2}$ 349-359. (doi:10.1016/0044-8486(94)00364-T)

Sathiyaa R \& Vijayan MM 2003 Autoregulation of glucocorticoid receptor by cortisol in rainbow trout hepatocytes. American Journal of Physiology. Cell Physiology 284 1508-1515.

Schlueter P, Peng G, Westerfield M \& Duan C 2007 Insulin-like growth factor signaling regulates zebrafish embryo growth and development by promoting cell survival and cell cycle progression. Cell Death and Differentiation 14 1095-1105. (doi:10.1038/sj.cdd.4402109)

Schreck CB 2010 Stress and fish reproduction: the role of allostasis and hormoesis. General and Comparative Endocrinology 156 549-556. (doi:10.1016/j.ygcen.2009.07.004)

Scott GR, Keir KR \& Schulte PM 2005 Effects of spironolactone and RU486 on gene expression and cell proliferation after freshwater transfer in the Euryhaline killifish. Journal of Comparative Physiology 175B 499-510. (doi:10.1007/s00360-005-0014-2)

Shiokawa K, Aso M, Kondo T, Uchiyama H, Kuroyanagi S, Takai JI, Takahashi S, Kajitani M, Kaito C, Sekimizu K et al. 2008 Gene expression in pre-MBT embryos and activation of maternally-inherited program of apoptosis to be executed at around MBT as a fail-safe mechanism in Xenopus early embryogenesis. Genetics 2 213-231.

Spiga F, Knight DM, Droste SK, Conway-Campbell B, Kershaw Y, MacSweeney CP, Thomson FJ, Craighead M, Peeters BWMM \& Lightman SL 2011 Differential effect of glucocorticoid receptor agonists on glucocorticoid receptor nuclear translocation and DNA binding. Journal of Psychopharmacology 25 211-221. (doi:10.1177/0269881109348175)

Stewart AA, Byron CR, Pondenis HC \& Stewart MC 2008 Effect of dexamethasone supplementation on chondrongenesis of equine mesenchymal stem cells. American Journal of Veterinary Research 69 1013-1021. (doi:10.2460/ajvr.69.8.1013)

Tandros W, Goldman AL, Babak T, Menzies F, Vardy L, Orr-Weaver T, Hughes TR, Westwood JT, Smilbert CA \& Lipshitz HD 2007 SMAUG is a major regulator of maternal mRNA destabilization in Drosophila and its translation is activated by the PAN GU kinase. Developmental Cell $\mathbf{1 2}$ 143-155. (doi:10.1016/j.devcel.2006.10.005)

Tandros W, Houston SA, Bashirulla A, Cooperstock RL, Semotok JL, Reed BH \& Lipshitz HD 2003 Regulation of maternal transcript destabilization during egg activation in Drosophila. Genetics 164 989-1001.

Tandros W \& Lipshitz HD 2009 The maternal-to-zygotic transition: a play in two acts. Development 136 3033-3042. (doi:10.1242/dev.033183)

Veillette PA, Serrano X, Garcia MM \& Specker JL 2007 Evidence for the onset of feedback regulation of cortisol in larval summer flounder. General and Comparative Endocrinology 154 105-110. (doi:10.1016/j.ygcen. 2007.05.033)

Veleiro AS, Alvarez LD, Eduardo SL \& Burton G 2010 Structure of the glucocorticoid receptor, a flexible protein that can adapt to different ligands. ChemMedChem 5 649-659. (doi:10.1002/cmdc.201000014) 
Vijayan MM, Aluru N \& Leatherland JF 2010 Stress response and the role of cortisol. In: Fish Diseases and Disorders. Volume 2, Non-Infectious Disorders, 2nd edn, pp 182-201. Eds JF Leatherland \& PTK Woo. New York: CABI Publishing.

Vijayan MM, Raptis S \& Sathiuyaa R 2003 Cortisol treatment affects glucocorticoid receptor and glucocorticoid-responsive genes in the liver of rainbow trout. General and Comparative Endocrinology 132 256-263. (doi:10.1016/S0016-6480(03)00092-3)

Vijayan MM, Reddy PK, Leatherland JF \& Moon TW 1994 The effects of cortisol on hepatocyte metabolism in rainbow trout: a study using the steroid analogue RU486. General and Comparative Endocrinology 96 75-84. (doi:10.1006/gcen.1994.1160)

Vizzini A, Vazzana M, Cammarata M \& Parrinello N 2007 Peritoneal cavity phagocytes from the teleost sea bass express a glucocorticoid receptor (cloned and sequenced) involved in genomic modulation of the in vitro chemiluminescence response to zymogen. General and Comparative Endocrinology 150 114-123. (doi:10.1016/j.ygcen.2006. 07.016)
Wood AW, Duan C \& Bern HA 2005 Insulin-like growth factor signaling in fish. International Review of Cytology 243 215-285.

Yada T, Muto K, Azuma T, Hyodo S \& Schreck CB 2005 Cortisol stimulates growth hormone gene expression in rainbow trout leucocytes in vitro. General and Comparative Endocrinology 142 248-255. (doi:10.1016/j.ygcen.2005.01.008)

Yamaguchi T, Yoshinaga N, Yazawa T, Gen K \& Kitano T 2010 Cortisol is involved in temperature-dependent sex determination in the Japanese flounder. Endocrinology 151 3900-3908. (doi:10.1210/en.2010-0228)

Zang S, Jonklaas J \& Danielsen M 2007 The glucocorticoid agonist activities of mifepristone (RU486) and progesterone are dependent on glucocorticoid receptor levels but not EC 50 values. Steroids 72 600-608. (doi:10.1016/ j.steroids.2007.03.012)

Received in final form 5 July 2012

Accepted 10 July 2012

Made available online as an Accepted Preprint 10 July 2012 